сугубо вербальное объяснение грамматического материала учителем. На следующем этапе работы авторы статьи планируют проанализировать возможные пути использования компьютерных игр и комиксов как эффективных средств оптимизации обучения грамматике английского языка.

Ключевые слова: средства наглядного обучения, визуализация грамматики, грамматическая компетентность, грамматическое упражнение, начальная школа.

Iryna B. MOROZOVA,

Doctor of Philol. Sc. (Grand PhD), Full Professor; Chair of English Grammar, Odessa I. I. Mechnikov National University; Odessa, 65058, Ukraine; e-mail: morpo@ukr.net; tel.: +38 050 6572043; ORCID ID: 0000-0002-19057563

Natalya V. NOVIKOVA,

Teacher of English of higher category, senior teacher of English, Odessa Junior School Specialising in the Intensive Study of English \# 119; 39 Zhukovskogo Street, Odessa, 65020, Ukraine; Natalia5959@ukr.net; tel.: +38 050 1450150; ORCID ID: 0000-0002-9311-2639

\title{
WHAT IS VISIBLE IS CLEAR: VISUAL AIDS AS A MEANS OF TEACHING GRAMMAR IN JUNIOR SCHOOL
}

Summary. The article faces the problem of visualizing grammatical material as an effective methodological approach to teaching grammar in junior schools. Visual aids used in teaching grammar represent didactic material as pictures, sketches, animated cartoons, films, flash-cards, etc. Employing eye-catching images for the purpose of teaching a foreign language has ever been and still remains a key-question not only in this country, but also abroad. The discussion of physical layers of perception as a specific means of acquiring and accumulating knowledge about the surrounding world is motivated by our wish to prove that visual aids provide children with a double support for their newly-acquired knowledge, granting a better comprehension of the necessary amount of grammatical material. On the one hand, junior children are used to reading books with illustrations or pictures or watching films on the screen for their personal enjoyment. On the other hand, visualization of grammar rules / system gives them an opportunity to conserve the grammatical material required by the school programme on two levels, one of logic and the other of emotions. Images that already exist in their minds as fixed entities associated with a certain emotional feedback are reflected in their conscience again, this time as ready-to-use grammatical forms and speech patterns. The urgency of the problem studied follows from the steady interest of teachers to the method of visualization itself and is motivated by the lack of grammatical exercises and instructions based on the given approach. The object of our study is a set of different types of visual aids used by teachers in the process of explaining and drilling grammatical rules. The subject of this work is the psychological essence of the grammar-visualization method in junior school practice. The objective of this paper consists in singling out the most effective visual aids used for the purpose of teaching grammar in junior school. The authors argue that visualizing different aspects of English grammar by means of employing various images in class during the lesson (like children's favourite fairy-tales, characters' pictures or animated cartoons personages) makes the teachers' explanation of grammar sound easier for the pupils and contributes to enhancing the kid's grammatical competence by approximately $15 \%$ altogether. The near perspectives of our future investigation we see in studying computer games and comics as a means of visualizing grammar.

Key words: visual aids, visualization of grammar, grammatical competence, grammar exercise, junior school.

Статтю отримано 05.10.2018 p.

http://dx.doi.org/10.18524/2307-4558.2018.30.154333

УДК [811.111+811.161.1]'25:347.78.034:801.733

САПРЫГИНА Нина Вадимовна,

кандидат филологических наук, доцент кафедры социальной и прикладной психологии Одесского национального университета имени И. И. Мечникова; ул. Дворянская, 2, г. Одесса, 65082, Украина; тел.: +38(048)7236303; e-mail: vadimovan@rambler.ru

\section{РУССКИЕ ПЕРЕВОДЫ СОНЕТА 105 В. ШЕКСПИРА: СЕМАНТИЧЕСКИЙ АНАЛИЗ И НОВАЯ ИНТЕРПРЕТАЦИЯ}

\begin{abstract}
Аннотация. Мировая ценность художественного наследия Шекспира и рост количества русских переводов сонетов требуют углублённого изучения их смыслов и символов и семантического анализа с выходом на новую интерпретацию. Понимание как способ функционирования текста в сознании читателя требует изучения значений и смыслов методами психолингвистики и герменевтики. На интерпретацию сонетов, в том числе на их русские переводы, влияют три различных версии. В соответствии с первой, сонеты Шекспира не автобиографичны, не отражают его внутренней жизни; он не был искренен, так как писал по заказу, учитывал личную выгоду, использовал куртуазные традиции и поэтические штампы. В соответствии со второй, сонеты автобиографичны и отражают переживания автора при невы-
\end{abstract}


ясненных обстоятельствах. По третьей версии, загадку сонетов объясняют предположением о любви поэта к мужчине и необходимостью скрывать это. Дель статьи - выявить не рассмотренные ранее смыслы сонета 105 В. Шекспира. Объект исследования - сонет 105 Шекспира в оригинале и некоторые русские переводы. Методы изучения материала - семантико-смысловой анализ, сопоставительный анализ, историко-культурная интерпретация. Предпринятый семантико-смысловой анализ сонета включает в себя психологический и исторический аспекты и интертекстуальные взаимосвязи с ключевыми строками других сонетов, в которых утверждаются ценности автора. В результате исследования мы пришли к заключению, что сонет 105 Шекспира представляет собой символическое и индивидуально-поэтическое осмысление христианской идеи и символа Святой Троицы, вдохновляющей поэта на творчество. Выводы. Сонет 105 трактуют как адресованный другу, но на самом деле герой - божество. Религиозная идея в сонете 105 не декларируется прямо, поскольку в период его создания имелись острые межконфессиональные противоречия в Великобритании.

Ключевые слова: Шекспир, сонеты, сонет 105, художественный перевод, понимание, интерпретация, семантика, смыслы, символы, христианство, Святая Троица.

Постановка проблемы. Рост числа русских переводов сонетов Шекспира говорит об актуальной потребности общения с поэзией Великого Барда, о неудовлетворённости предыдущими переводами и стремлении постичь их загадку. Ответ пробовали искать в версиях, кто такой Шекспир. Однако дажее новые версии пока не прояснили понимания.

В целом, проблема понимания и интерпретации сонетов выглядит так. Версия 1. Шекспир писал сонеты по заказу, пользуясь куртуазными клише и стереотипами, чтобы угодить заказчику (ам) знатным господам. Эту версию подносят школьникам и неанглоязычным читателям. Но эта версия значит, что Шекспир неискренен в сонетах.

Версия 2, альтернативная. Шекспир был искренним. Шекспир в сонетах открывает свою душу и намекает на обстоятельства своей жизни, хотя они и не ясны из текстов.

Из версии 1 следует, что ценность сонетов невелика. Тем не менее, их ценность неоспорима, и это противоречие создаёт ощущение непонятности. Во второй версии неясного значительно больше. Попытка разобраться в неясностях не исключает рассмотрения проблемы авторства Шекспира. Контаминацию между 1-й и 2-й версиями, или 3-ю версию, высказал шекспировед Эдмунд Мэлон в конце 18 века. По его мнению, сонеты с 1 по 126 адресованы покровителю Шекспира, а сам Шекспир был мужчиной нетрадиционной ориентации, и это необходимо было скрывать. Здесь важно защитить Шекспира от несправедливых предположений и подмены ценностей.

Связь с предыдущими исследованиями. По нашим подсчётам данных о публикациях русских переводов сонетов Шекспира, в настоящее время имеется свыше 30 полных переводов различных авторов на русский язык, изданных отдельными книгами. Среди них лидируют по количеству изданий и читательской популярности (о чём можно судить также по перепубликациям в Интернете) переводы Самуила Маршака. В недавнее академическое издание русских переводов сонетов включили, помимо них, переводы Модеста Чайковского, А. Финкеля, В. Микушевича, Игнатия Ивановского [15]. К тому же, есть значительное количество переводов в Интернете, среди них - полные переводы, не публиковавшиеся отдельными книгами. Часть из них выполняется любителями-энтузиастами. Есть форумы по переводам сонетов и конкурсы по переводам отдельных сонетов. Среди создателей полных переводов сонетов Шекспира на русский язык выделяется харьковчанка, доктор физико-математических наук Ирина Чупис [14], обладающая тонким творческим почерком. Детальный обзор переводов сонетов Шекспира на русский язык, их стилистических и смысловых особенностей и рецепции образа автора сонетов представлен в работах Е. А. Первушиной [6].

Постановка исследовательских задач. Цель данной статьи - выявить не рассмотренные ранее смыслы сонета 105 В. Шекспира. Материал исследования - сонет 105 Шекспира в оригинале и некоторые его русские переводы. Методы изучения материала: семантико-смысловой анализ, сопоставительный анализ, историко-культурная интерпретация. За основу анализа мы принимаем указанную выше версию 2, в соответствии с которой Шекспир был искренним и рассказывал в сонете о своей жизни. Предпримем также семантико-смысловой анализ некоторых других сонетов, выводя информацию только из текстов.

Изложение основного материала. В поэзии есть логика, хотя и не столь прямолинейная, как в науке. Поэтому отдельные высказывания в разных стихотворениях одного автора непротиворечивы с точки зрения авторской идеи. Парадоксы, которых много в поэзии, это мнимые противоречия, ибо они показывают диалектическую сложность жизни. В психологии есть принцип единства личности, сознания и деятельности. Личность может менять свои взгляды, но не радикально, а в сторону усложнения и развития.

Переводчики предпочитают переводить то, что поняли. Гипотеза Мэлона частично объясняет загадочность сонетов. Но даже понятное не всегда удаётся передать поэтическим словом. Так, Самуил Маршак не мог перевести (хромого вождя) из сонета 66. Тем более сложно передавать загадочность смыслов, не понятых переводчиками.

Традиционный анализ текста отводил семантику текста к области изучения языковедов, смыслы - в основном литературоведам. $K$ счастью, в этом вопросе есть существенное продвижение. Лингвистический, мотивный, структурный, сюжетный и другие уровни могут объединяться в одном анализе с целью изучения личности и творчества одного автора, стремлением раскрыть его творческую задачу (см., напр., Ж⿱. Силади [9], В. С. Хазиев [12], Е. А. Иваньшина [3], Е. Л. Соснина [10]). 
Мы используем разрабатываемый нами семантико-смысловой подход и анализ [8]. Традиции семантико-смыслового подхода мы видим в идеях академика Л. В. Щербы - в его подетальном комментировании текстов Пушкина и Лермонтова [17]. Идеи такого комментирования были в своё время использованы в школьном преподавании (ср. лингвистический анализ художественного текста - Л. А. Новиков [5]), но углублённого изучения текста в школьной практике быть не могло.

Основные отличия нашего анализа от традиционного следующие.

Семантика: семы или семантические множители есть составляющие содержания. Содержание есть называние, указание или описание субъектов, предметов, действий и процессов, признаков, обстоятельств, фактов и событий, то есть тот перечень семантических характеристик, который соответствует наполнению грамматической структуры предложений.

Смыслы. Под смыслами (sense) понимаем цели сообщения, темы, коммуникативные намерения, основную идею, резюмирующую идею (мораль). Смыслы отвечают на вопросы (почему» и “зачем» и пересказываются при помощи метатекста, который также состоит из сем, но более обобщённых. Понятие смысла лучше разработано в психологии, чем в филологии (см. Д. А. Леонтьев [4], С. Франкл [11]). Будучи психологическими образованиями по своей сути, смыслы лучше передаются образами, ритмами, интонациями, чем пересказом. Изначальная неединственность смыслов (из-за чего мы используем термин (смысл) во множественном числе) вызывает проблему их интерпретации. В некоторых текстах смысл равен содержанию, то есть целью является требование усвоения содержания реципиентом (в учебных, научных текстах, справочниках, протоколах и т. п.). В обыденной и в художественной речи смыслы и содержание могут существенно расходиться. Напр., Закрой дверь с той стороны - требование не закрыть дверь, а удалиться.

1. Анализируем не столько слова, сколько семы. Разные слова могут содержать одну и ту же сему, например, синонимический ряд. Ищем семантические поля этих сем. Используем краткий пересказ - метатекст.

2. Обращаясь к психологии, с помощью ключевых слов и сем пытаемся понять конфликт автора и героев, конфоликтную ситуацию, эмоции (переживания), которые она вызывает.

3. Обращаемся к биографическим данным автора, ищем проблемные ситуации и конфликты, ищем их аналоги в текстах автора.

4. Ищем социальное окружение автора, его друзей, конкурентов, его противников, обстоятельства и реалии, его окружающие.

5. Рассматриваем историческую ситуацию автора и ситуацию, к которой он обращался, если она удалена от него в прошлое. Ищем в них актуальные для автора конфоликты.

В конкретном тексте могут быть задействованы далеко не все перечисленные области анализа.

Перейдём к анализу сонета 105 [цит. по: 15].

Let not my love be call'd idolatry,

Nor my beloved as an idol show,

Since all alike my songs and praises be

To one, of one, still such, and ever so.

Kind is my love to-day, to-morrow kind,

Still constant in a wondrous excellence;

Therefore my verse to constancy confined,

One thing expressing, leaves out difference.

'Fair, kind and true' is all my argument,

'Fair, kind, and true' varying to other words;

And in this change is my invention spent,

Three themes in one, which wondrous scope affords.

'Fair, kind, and true,' have often lived alone,

Which three till now never kept seat in one.

Приведу собственный подстрочник.

Не нужно ни мою любовь называть идолопоклонством (идолослужением), ни мою любимую (любимого) показывать как идола, с тех пор как всё подобное моим песням и моим хвалам было бы к одному (к одной, $к$ единому, $к$ единой), от одной, всё такой же и вечно такой. Добра моя любовь сегодня, добра и завтра, всё так же постоянна в иудесном превосходстве. Так и мои стихи ограничень постоянством, одну вещь изображают, оставляя в стороне различия. 'Fair, kind, and true' - вот весь мой спор (довод, аргумент), 'Fair, kind, and true', — (я говорю) разнообразными словами, и в этом изменении тратится моя выдумка; три темы в одной, которые позволяют открыть чудный простор (кругозор). 'Fair, kind, and true' часто жили в одиночестве, в котором три до нынешнего времени никогда не садились в одном (едином).

Создание подстрочника труднее, чем стихотворный перевод, где допускаются пропуски (лакуны) и вставки (то, что переводчики называют отсебятиной) (К. Чуковский [13]). Шекспир особым образом использует полисемию. Обычно с помощью контекста реализуется одно значение многозначного слова, а все другие исключаются. А в сонетах ключевые слова используются одновременно в не- 
скольких значениях. Не случайно Пушкин обозначил их как (игру». Аналогии этого приёма есть в библейских текстах.

В русской поэзии таких случаев мало. Пример можно найти в стихотворении Блока “Девушка пела в церковном хоре»: И голос был сладок, и луи был тонок, И только вьсоко, у Царских Врат, Причастный Тайнам, - плакал ребёнок О том, ито никто не придёт назад. Причастный тайнам - 'причастившийся святых тайн, получивший причастие в церковном обряде' (это значение было непонятно советским читателям) и 'тот, кто мистически постиг тайны бытия, таинственное будущее'.

Приведём также перевод сонета 105 Маршака.

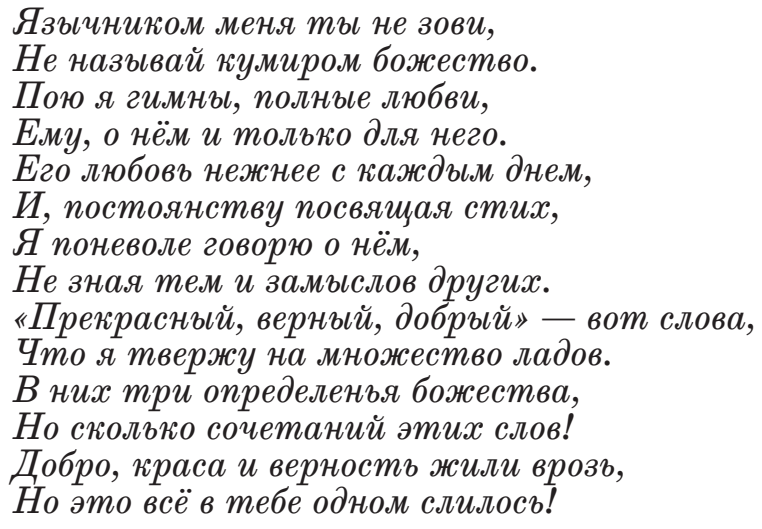

Здесь недостаток в выражении: скольжо сочетаний этих слов. Математик уточнит, что из трёх слов возможно всего шесть сочетаний. Другое дело семы. Они могут быть переданы, как сказано у Шекспира, (разными словами». Неудачно слово поневоле, так как мы уже приняли за основу, что Шекспир искренен и хвалу возносит добровольно.

Ключевые слова fair, kind, and true многозначны. Это прилагательные, но могут быть рассмотрены как существительные (субстантивация).

Kind - добрый, милый, славный, сердечный, внимательный. True - честный, правдивый, верный, настоящий, истинный, а также правда (сущ.), и это далеко не полный семантический ряд. Шекспироведы отмечают, что Шекспир играет значениями 'светловолосый' (друг) и 'прекрасный' (он же) (Аникст [1]).

Значит, fair в индивидуально-авторском значении - 'светлый'. Это соответствует этимологии. Fire - 'огонь', 'пламя', то есть источающее свет. Обратим внимание на ещё одну, необычную, интерпретацию этих ключевых слов. Она принадлежит философу идеалистического направления. Указано сходство с триадой Платона (Истина, добро и красота», что уже отмечено шекспироведами, но и необычна интерпретация семантики слова fair.

(Первое общее, что сразу ухватывает мысль, это триада, которая не только проходит рефреном через сонет 105 Шекспира, но и светится во всём его творчестве: (Fair, kind, true». Переводы здесь разные: и (fair») переводят как прекрасное и милое, и (kind» переводят как правду и благо, и (true» переводят как верность и чистоту, и т. д., но суть одна: тут у Шекспира извечное, тянущееся ещё от Платона триединство с более соответствующим переводом: красота, добро, истина. (...) Анализ триады (Fair, kind, true» у Шекспира показывает, что в общем-то с kind и true у него особых методологических проблем нет. А вот (...) слово fair используется им почти в трети сонетов, и используется в веере разнообразных, но близких по смыслу значений: прекрасный, истинный, добрый, благой, светлый, совершенный, сияющй, лучезарный, идеальный. Учитывая, что оно практически всегда употребляется при описании лирического собеседника Шекспира как характеристика его природы и атрибут его сущности, то вполне логично переводить его в метафизическом плане прилагательным (идеальный) от слова (идея), памятуя и об этическом нюансе идеала и об эстетическом плане идейного творчества» [2]. Здесь важна мысль, что речь в сонете идёт не о человеческом существе, а о метаффизической сущности.

В переводе Маршака дважды упоминается “божество»: Не называй кумиром божество. $B$ них три определенья божества.

Обратимся к первой строке. Не нужно мою любовъ звать идолопожлонством. Платон - носитель тайного знания, но всё же - не христианин.

Моя любовь - не идол (не кумир). То есть поэт не восхваляет, не обожествляет любимую (или любимого). А также не хочет преклоняться перед сильными мира сего (ср. библейскую заповедь Не сотвори кумира).

Предполагаемое лицо - герой-адресат сонетов - в сонете 105 не назван на mы (thou, you). Такую адресацию добавляют переводчики. Настоящий адресат - читатель (или посторонний), который может назвать поэта идолопоклонником. Переводчики следуют версии Мэлона: адресат у них — любимый мужчина. 
Субъект или явление, о котором идёт речь, назван во 2-й строке beloved - 'a much loved person', 'любимый (ая)'. Это всё же человек. Но далее в тексте оригинала любимый (любимая) исчезает.

В переводах субъект назван красавица (Н. Гербель), любилый (А. Финкель), господин (В. Микушевич), мильй (С. Турухтанов, И. Чупис), возлюбленный (А. Шаракшанэ, С. Степанов), он (С. Степанов). Слово кумир появляется в переводе Игоря Фрадкина, в полном противоречии авторской идее.

Переводчики используют $B ы$ (И. Чупис), mы в соединении с beloved, чего в оригинале нет. Особенно показателен перевод замка сонета. В основном, встречается ты, которого в оригинале нет.

Три качества так часто жили врозь, // Теперь единство их в тебе сошлось (Р. Бадыгов). Прекрасный, добрый, верный - чудо в том, // Что это всё слилось в тебе одном (Андрей Кузнецов). Три темы, мощно слившихся в одну. // Они так тесно встретились втроём // В неповторимом облике твоём (Игн. Ивановский). 'Красивый, добрый, честный' - ходят врозь. // Но вместе быть в тебе им довелось (Валентин Савин) [7]. У некоторых переводчиков сохраняется неопределённое одно: (Прекрасный, добрый, верный) - врозь подчас, // Но вот все три в одном на этот раз (С. Степанов).

В сонете 130, памятном в переводе Маршака (“Её глаза на звёзды не похожи»), поэт возражает против куртуазных штампов и лести, то есть свидетельствует о своей искренности. Но в сонете 105 'ю одной-единой', 'от одной' - есть колоссальное возвышение роли этого единого. В таком случае, понятие love 'любовь' в сонете относится не к человеческой сущности.

Какие же ценности поэт противопоставляет языческим? Христианские.

В первом катрене сонета есть: my song sand praises be to one, of one. Сp. [Верую...] И в Духа Святого, Господа Жиивотворящего, иже от Отца исходящаго, иже со Отцем и Сыном споклоняема и сславима... (Восьмой член Символ веры) (Здесь и далее выделено мною. - Н. С.). Здесь видим совпадающие семы 'единое', 'исходить, быть источником', 'восхвалять'.

Во втором катрене есть: still such, and ever so - всё такой(ая) же и вечно тот (та) же. Ср. ныне u присно (англ. now and ever). То есть уже 4 семантических указания на христианские священные символы и молитвы. В таком случае, три добродетели - Красота, Добро и Истина, - по Шекспиру, это добродетели христианские.

Последняя строфа-замок. 'Fair, kind, and true,' have often live dalone, which three till now never kept seat in one; kept seat буквально: остались сидеть. Возникает образ. Три высших христианских добродетели, которые сидят вместе. Икона Святой Троицы Андрея Рублёва. Поэт жил в другом культурном пространстве. Но в трудах Блаженного Августина получила богословское толкование идея ветхозаветной Святой Троицы, к которой восходит образ иконы Андрея Рублёва. Это три ангела, пришедшие к Аврааму, которые воссели за столом (5-я совпадающая сема).

В сонете 105 Шекспир воспевает Святую Троицу.

Если наше предположение об этом смысле сонета верно, то должны быть и другие смысловые совпадения. Проверяем христианскими толкованиями.

[Верую...] И во единого Господа Иисуса Христа, Сына Божия, Единородного, иже от Отца рожденного прежде всех век: Света от Света, Бога истинна от Бога истинна, рожденна, несотворенна, единосущна Отцу, Имже вся быша. (Второй член Символа веры). Таким образом, ещё серия совпадений: семы 'единство' (нами уже названо), 'свет', 'истина' (6-я и 7-я семы).

Отсюда понятно, что это не совпадения, а соответствия. На 14 строк приходится 7 семантических единиц, относящихся к сущности христианского вероучения, сформулированной в Символе веры. Наше понимание соответствует смыслу сонета. Сонет описывает идею христианской святой Троицы.

В ходе подготовки этой статьи мы обнаружили ещё один перевод, близкий к нашей интерпретации.

“Я в идолопоклонство не впадал: Люблю не истукана - человека! Он для меня не идол - идеал, Единый ныне, присно и вовеки. Он добр сегодня, завтра и всегда, Всегда единый в совершенстве дивном; Мой стих не сменит тему никогда, Любовью переполненный единой. "Добр, верен, белокур" - да повторятся Святою троищей моей любви слова! Мои стихи - узоры вариаций - Тем mриединых породит канва. “Добр, верен, белокур) - три этих слова В тебе одном воплощены любовью" [18].

Переводчица добросовестно воссоздала детали содержания сонета, в котором обнаружила семы, относящиеся к христианской религии и её символам. Однако смысл был ею не понят. Автор перевода полагала, что идёт приспособление христианской символики к восхвалению некоей личности. Если бы это было так, это и было бы идолопоклонством. Шекспир же это отрицает.

Символическая могила Шекспира находится в городе Стратфорде-на-Эйвоне в храме Святой Троицы. Это говорит о том, что идея Святой Троицы была для Шекспира важнейшей.

В Англии в эпоху Шекспира происходила борьба конфессий, и каноны англиканской церкви ещё не были окончательно сформированы. Не исключено, что Шекспир сам замаскировал религиозные темы в описаниях любовных переживаний, чтобы избежать цензуры. Самуил Маршак сумел приоткрыть религиозный смысл сонета 105.

Выводы. Таким образом, использование семантико-смыслового и сопоставительного анализа в сочетании с историко- и лингвосоциокультурной интерпретацией текста сонета 105 Шекспира 
и его разных переводов на русский язык позволило нам обнаружить в этом сонете символическое и индивидуально-поэтическое осмысление Шекспиром христианской идеи и символа Святой Троицы, вдохновляющей поэта на творчество. Следовательно, обычная трактовка сонета 105 как адресованного другу неверна. На самом деле, герой этого произведения - божество. Религиозная идея в сонете 105 не декларируется прямо, поскольку в период его создания имелись острые межконфессиональные противоречия в Великобритании. Этот вывод, сделанный на основе последовательного соответствия в четырнадцати строках семи семантических единиц, относящихся к сформулированной в Символе веры сущности христианского вероучения ('единое', 'быть источником', 'восхвалять', 'ныне и присно', 'восседать / быть основой', 'свет', 'истина'), даёт основания полагать, что и в некоторых других сонетах Шекспира под налётом семантической многозначности скрыты высокие смыслы христианского вероучения. Это делает наше исследование перспективным.

\section{Литература}

1. Аникст А. А. Комментарии // Шекспир У. Сонеты. На англ. яз. с параллельным русским текстом / сост. А. Н. Горбунов. М. : Радуга, 1984. С. 293-354.

2. Борчиков С. Шекспир и Соловьёв эгоургия и софиургия нового человека // Библиотека и фонотека Воздушного Замка. URL : https://lib.rmvoz.ru/bigzal/Shakespeare-and-Soloviev_egourgiya-and-sofiurgiya (Дата обращения: 10.07.2018).

3. Иваньшина Е. А. “Адам и Ева» Булгакова как невротический текст // Кормановские чтения : Статьи и материалы межвуз. науч. конф. (Ижевск, апрель, 2013) / ред.-сост. Д. И. Черашняя. Ижевск : Изд-во Удмуртского гос. ун-та, 2013. Вып. 12. С. 247-257.

4. Леонтьев Д. А. Психология смысла : природа, строение и динамика смысловой реальности. 2-е изд., испр. М. : Смысл, 2003. $487 \mathrm{c.}$

5. Новиков Л. А. Художественный текст и его анализ. М. : ЛКИ, 2007. 304 с.

6. Первушина Е. А. Сонеты Шекспира в России : переводческая рецепция XIX-XXI вв. : монография. Владивосток : Изд-во Дальневост. ун-та, 2010. 354 с.

7. Савин Валентин Алексеевич. Сонеты Шекспира // Журнал “Самиздат». 25.06.2012. URL : http://samlib.ru/s/ sawin_walentin_alekseewich/sonetyshekspira.shtml

8. Сапрыгина Н. В. Предисловие // Диалог автора и читателя : сб. статей. Saarbrücken : Lambert Academic Publishing, 2014. C. 3-7.

9. Силади Ж. Сосна, пальма и свет (соотношение звуковых повторов и поэтической семантики в стихотворении Лермонтова “На севере диком стоит одиноко...») // Docplayer. 14 c. URL : https://docplayer.ru/33997323-Sosnapalma-i-svet-sootnoshenie-zvukovyh-povtorov-i-poeticheskoy-semantiki-v-stihotvorenii-lermontova-na-severe-dikomstoit-odinoko-zhofiya-siladi.html (Дата обращения 25.06.2018)

10. Соснина Е. Л. Развитие образа в художественном мышлении М. Ю. Лермонтова // сб. науч. трудов, посв. 200-летнему юбилею М. Ю. Лермонтова. “Мы почти всегда иввиняем то, что понимаем....). Szombathely : University of West Hungary Press, 2014. Bibliotheca Slavica Savariensis. T. 14. C. 186-196. URL : https://www.openstarts.units. it/bitstream/10077/2429/1/11.pdf

11. Франкл В. Сказать жизни (Да!) : психолог в концлагере / пер. с нем. Д. Орлов, Д. Леонтьев. 2-е изд. М. : Смысл : Альпина нон-фикшн, 2011.237 с.

12. Хазиев В. С. Герменевтические упражнения над стихотворением Г. Гейне “Fichtenbaum» // Философия и общество. М. : МГУ, 2004. № 3. С. 105-116.

13. Чуковский К. И. Высокое искусство : принципы художественного перевода. М. : Азбука :Авалонъ, 2011. $442 \mathrm{c.}$

14. Чупис И. Е. Два духа, две любви. Сонеты Шекспира. Харьков : Факт, 2008. 216 с.

15. Шекспир У. Сонеты / ред. А. Н. Горбунов и др.]. М. : Наука, 2016. 884 с. $368 \mathrm{c}$.

16. Шекспир У. Сонеты. На англ. яз. с параллельным русским текстом / сост. А. Н. Горбунов. М. : Радуга, 1984.

17. Щерба Л. В. Опыты лингвистического толкования стихотворений. II. “Сосна» Лермонтова в сравнении с её немецким прототипом // Щерба Л. В. Избранные работы по русскому языку / АН СССР. Отд. лит. и яз. М. : Гос. учеб.-пед. изд-во Мин-ва просвещения РСФСР, 1957. С. 97-109.

18. Sonnet 105 - Сонет 105 : Оригинал : Sonnet 105, Уильям Шекспир ; Перевод с английского : Иванова Наталья Владимировна // Музыка перевода, 03.12.2013. URL : http://mustran.ru/2013/work/1505 (Дата обращения: 18.05.2018).

19. (The) sonnets, Quarto 1 : Shake-Speares Sonnets. Neuer before Imprinted. London : Thomas Thorpe, G. Eld, 1609 // Facsimileinfo. Internet Shakespeare editions. URL : http://internetshakespeare.uvic.ca/Library/facsimile/overview/book/Q1_Son.html

\section{References}

1. Anikst, A. A. (1984), "Comments», Shakespeare, W. Sonnets. In English. lang. with parallel Russian text ["Kommentarii), Shekspir U., Sonety : na angl. yaz. s parallel'nym russkim tekstom / sost. A. N. Gorbunov], Raduga, Moscow, pp. 293-354.

2. Borchikov, S. "Shakespeare and Solovyov, egourgy and sophiurgy of a new person", Library and record library of the Air Castle ["Shekspir i Solov'yov egourgiya i sofiurgiya novogo cheloveka», Biblioteka $i$ fonoteka Vozdushnogo Zamka], URL: https://lib.rmvoz.ru/bigzal/Shakespeare-and-Soloviev_egourgiya-and-sofiurgiya (Revised: 07.07.2018).

3. Ivanshina, Ye. A. (2013), " "Adam and Eve» of Bulgakov as a neurotic text», Korman readings : Proceedings of Intercollegiate scientific conf. (Izhevsk, April, 2013) ["(Adam i Yeva» Bulgakova kak nevroticheskiy tekst», Kormanovskiye 
chteniya : Stat'i i materialy mezhvuz. nauch. konf. (Izhevsk, aprel', 2013)], ed.-comp. D. I. Cherashnyaya, Publ. House of the Udmurt State Univ., Izhevsk, vol. 12, pp. 247-257.

4. Leontiev, D. A. (2003), Psychology of Meaning : Nature, Structure and Dynamics of Semantic Reality. 2nd ed., corr. [Psikhologiya smysla : priroda, stroyeniye $i$ dinamika smyslovoy real'nosti. 2-e izd., ispr.], Smysl, Moscow, $487 \mathrm{p}$. $304 \mathrm{p}$

5. Novikov, L. A. (2007), The artistic text and its analysis [Khudozhestvennyy tekst i yego analiz], LKI Publ. House,

6. Pervushina, E. A. (2010), Shakespeare's sonnets in Russia : translation reception of the XIX-XXI centuries : monograph [Sonety Shekspira $v$ Rossii : perevodcheskaya retseptsiya XIX-XXI vv. : monografiya], Publishing House of the Far East University, Vladivostok, 2010. $354 \mathrm{p}$.

7. Savin, V. A. (2012), "Shakespeare's Sonnets», Samizdat Journal ["Sonety Shekspira», Zhurnal "Samizdat», 25.06.2012], available at: http://samlib.ru/s/sawin_walentin_alekseewich/sonetyshekspira.shtml

8. Saprygina, N. V. (2014), "Preface", Dialogue of the author and the reader : collection of articles ["Predisloviye", Dialog avtora $i$ chitatelya : sbornik statey], Lambert Academic Publishing, pp. 3-7.

9. Szilágyi, Zs. "Pine, palm tree and light (the ratio of sound repetitions and poetic semantics in Lermontov's poem (In the wild north...»)", Docplayer ["Sosna, pal'ma i svet (sootnosheniye zvukovykh povtorov i poeticheskoy semantiki v stikhotvorenii Lermontova (Na severe dikom stoit odinoko...»)), Docplayer], 14 p., available at : https://docplayer. $\mathrm{ru} / 33997323$-Sosna-palma-i-svet-sootnoshenie-zvukovyh-povtorov-i-poeticheskoy-semantiki-v-stihotvorenii-lermontova-na-severe-dikom-stoit-odinoko-zhofiya- siladi.html (Appeal date 25/06/2018)

10. Sosnina, E. L. (2014), "The development of the image in the artistic thinking of M. Yu. Lermontov», Collection of scientific works devoted The 200th anniversary of M. Yu. Lermontov : "We almost always excuse what we understand...", Bibliotheca Slavica Savariensis ["Razvitiye obraza v khudozhestvennom myshlenii M. Yu. Lermontova»: Sbornik nauch. trudov, posv. 200-letnemu yubileyu M. Yu. Lermontova, "My pochti vsegda izvinyayem to, chto ponimayem...», Bibliotheca Slavica Savariensis], University of West Hungary Press, Szombathely, vol. 14, pp. 186-196, available at : https:// www.openstarts.units.it/bitstream/10077/2429/1/11.pdf

11. Frankl, V. (2011), Say to Life "Yes!» : psychologist in a concentration camp / transl. from German. 2nd ed. [Skazat' zhizni “Da!» : psikholog v kontslagere / per. s nemetskogo D. Orlov, D. Leont'yev. 2-e izd.], Smysl ; Alpina non-fiction, Moscow, $237 \mathrm{p}$.

12. Khaziev, V. S. (2004), "Hermeneutic exercises on the poem by G. Heine "Fichtenbaum»), Philosophy and Society [Germenevticheskiye uprazhneniya nad stikhotvoreniyem G. Geyne "Fichtenbaum», Filosofiya $i$ obshchestvo], Moscow State University, Moscow, vol. 3. pp. 105-116.

13. Chukovsky, K. I. (2011), High Art : Principles of Literary Translation [Vysokoye iskusstvo : printsipy khudozhestvennogo perevoda], Azbuka : Avalon, Moscow, 442 p.

14. Chupis, I. Ye. (2008), Two spirits, two love. Shakespeare's Sonnets [Dva dukha, dve lyubvi. Sonety Shekspira], Fakt, Kharkov, $216 \mathrm{p}$.

15. Shakespeare, W. (2016), Sonnets [Sonety], ed. A. N. Gorbunov et al., Nauka, Moscow, 884 p.

16. Shakespeare, W. (1984), Sonnets : In English language with parallel Russian text [Sonety : na angl. yaz. s parallel'nym russkim tekstom ], comp. A. N. Gorbunov, Raduga, Moscow, 368 p.

17. Shcherba, L. V. (1957), "Experiments of the linguistic interpretation of poems. II. "The Pine" of Lermontov in comparison with its German prototype», Selected works on the Russian language ["Opyty lingvisticheskogo tolkovaniya stikhotvoreniy. II. "Sosna» Lermontova v sravnenii s yeyo nemetskim prototipom», Shcherba L. V. Izbrannyye raboty po russkomu yazyku], Academy of Sciences of the USSR, The Literature and Language Department, Uchpedgiz, Moscow, pp. $97-109$.

18. "Sonnet 105 - Sonnet 105, Original: Sonnet 105 by William Shakespeare; Translation from English by Natalia Ivanova», Music Translation (12/03/2013) ["Sonnet 105 - Sonet 105 : Original : Sonnet 105, Uil'yam Shekspir ; Perevod s angliyskogo : Ivanova Natal'ya Vladimirovna", Muzyka perevoda], available at : http://mustran.ru/2013/ work/1505 (Appeal Date: 05/18/2018).

19. (The) sonnets, Quarto 1 (1609), Shake-Speares Sonnets. Neuer before Imprinted, Thomas Thorpe, G. Eld, London, Facsimileinfo. Internet Shakespeare editions, available at : http://internetshakespeare.uvic.ca/Library/facsimile/ overview/book/Q1_Son.html

\section{САПРИГІНА Ніна Вадимівна,}

кандидат філологічних наук, доцент кафедри соціальної та прикладної психології

Одеського національного університету імені І. І. Мечникова; вул. Дворянська, 2, м. Одеса, 65082, Україна;

тел.: +38 (048) 7236303; e-mail: vadimovan@rambler.ru

\section{РОСІЙСЬКІ ПЕРЕКЛАДИ СОНЕТА 105 В. ПІЕКСПІРА: СЕМАНТИЧНИЙ АНАЛІЗ І НОВА ІНТЕРПРЕТАЦІЯ}

Анотація. Світова цінність художньої спадщини Шекспіра і зростання кількості російських перекладів сонетів вимагають поглибленого вивчення їхніх смислів і символів і семантичного аналізу з виходом на нову інтерпретацію. Розуміння як спосіб функціонування тексту в свідомості читача вимагає вивчення значень і смислів методами психолінгвістики і герменевтики. На інтерпретацію сонетів, у тому числі на їх російські переклади, впливають три різних версії. Відповідно до першої, сонети Шекспіра автобіограбічні, не відображіають його внутрішнього життя; він не був щирий, оскільки писав на замовлення, враховував особисту вигоду, використовував куртуазні традиції та поетичні штампи. Відповідно до другої, сонети автобіографічні і відображають переживання автора за нез'ясованих обставин. За третьою версією, загадку сонетів пояснюють припущенням про любов поета до чоловіка і необхідністю приховувати це. Мета статті - виявити не розглянуті раніше смисли сонета 105 В. Шекспіра. Об'єкт дослідження - сонет 105 Шекспіра в оригіналі та деякі російські переклади. Методи вивчення матеріалу - семантико-смисловий аналіз, порівняльний аналіз, історико-культурна інтерпретація. Зроблений семантико-смисловий аналіз сонета включає в себе психологічний та історичний аспекти, а також інтертекстуальні взаємозв'язки з ключовими рядками інших сонетів, де затверджуються цінності автора. У результаті дослідження сонета 105 Шекспіра ми прийшли до розуміння, що цей 
сонет являє собою символічне й індивідуально-поетичне осмислення християнської ідеї та символу Святої Трійці, яка надихала поета на творчість. Висновки. Сонет 105 трактують як адресований другу, але справжній герой - божество. Релігійна ідея в сонеті 105 не декларується прямо, оскільки в період його створення були гострі міжконфесійні протиріччя у Великобританії.

Ключові слова: Шекспір, сонети, сонет 105, художній переклад, розуміння, інтерпретація, семантика, смисли, символи, християнство, Свята Трійця.

\section{Nina V. SAPRYGINA,}

Candidate of Philological Sciences, Associate Professor of the Department of Social and Applied Psychology of Odessa I. I. Mechnikov National University; 2 Dvoryanska st., Odessa, 65082, Ukraine;

tel. : +38 (048) 7236303; e-mail: vadimovan@rambler.ru

\section{RUSSIAN TRANSLATIONS OF THE SONNET 105 BY WILLIAM SHAKESPEARE - SEMANTIC-AND-SENSE ANALYSIS AND A NEW INTERPRETATION}

Summary. The world value of the artistic heritage of Shakespeare and the growth in the number of Russian translations of his sonnets require an in-depth study of their meanings and symbols and semantic-and-sense analysis with a new interpretation. Understanding as a way of functioning of a literary text in readers' mind requires the study of meanings and ideas using methods of psycholinguistics and hermeneutics. Objective. To clear the main idea of the W. Shakespeare's sonnet 105. Material: Sonnet 105 by Shakespeare in the original and some Russian translations. Methods: semantic-and-sense analysis, comparative analysis, historical and cultural interpretation.

The interpretation of the sonnets, including their Russian translations, is influenced by three versions: 1 . Shakespeare wrote on the order or wanting to gain the benefits of patronage, used courteous poetic traditions and clichés and was not sincere. Sonnets are not autobiographical and do not reflect the author's inner life. 2. Sonnets are autobiographical; reflect the author's experiences under unclear circumstances. 3. Shakespeare loved a man, and this circumstance required to hide unconventional relations. The third version has become popular. The semantic-and-sense analysis of the sonnet 105 includes psychological and historical aspects and intertextual relations with the key lines of other sonnets, in which the author's values are affirmed. If these statements are consistent, the sonnet tells not about a human being. Results. Shakespeare's sonnet 105 is a symbolic and individual poetic interpretation of the Christian idea of the Holy Trinity, which inspired the poet's imagination. Conclusions. The sonnet 105 is treated as referring to a friend, but in fact the "hero" is a godhead. In the sonnet 105 the religious idea is not declared directly, which may be explained by the confessional contradictions in that period.

Key words: Shakespeare, sonnets, sonnet 105, translation, understanding, interpretation, semantics, meanings, symbols, Christianity, Holy Trinity.

Статтю отримано 28.08.2018 p. 